\title{
Farm Level Evaluation of T. Aman Rice Cultivation In Selected Saline and Non-Saline Areas of Bangladesh
}

\author{
Mohammad Chhiddikur Rahman ${ }^{1,}$ Md Abu Bakr Siddique \& Md Abdus Salam² \\ Md Faizul Kabir ${ }^{3}$ and Md Shakil Mahamud ${ }^{4}$ \\ ${ }^{1 \& 3}$ Scientific Officer, ${ }^{2}$ Principal Scientific Officer \& Senior Scientific Officer, Bangladesh Rice Research \\ Institute, Gazipur-1701 and ${ }^{4}$ Senior Assistant Secretary, Ministry of Public Administration, Bangladesh.
}

\begin{abstract}
This comparative study was conducted within a selected coastal empoldered area (as saline area) and other selected non-saline districts of Bangladesh, during the period 2011-12 with a view to comparing the profitability and technical efficiency of $T$. Aman rice growers. The study revealed that $T$. Aman rice production was found profitable in both of saline and non-saline but the realistic favor the views that economic return is quite in non-saline areas. The returns per taka investment in both study areas were 1.75 and 1.82 , respectively. The estimated result showed that the average level of technical efficiencies of the sample farmers were about $70.70 \%$ and $87.50 \%$ for the saline and non-saline farms, respectively implying that given the existing technology and level of inputs, the output could be increased by $29 \%$ and $12 \%$, respectively. Farmer's education and training had positive significant effect on T. Aman rice production. The age of the sampled farmers' had significant positive impact on farming efficiency in the non-saline farms but it was negative on the saline area. The salinity had significant impact on the farming efficiency of T. Aman rice farmers'. The farmers of the nonsaline areas were technically more efficient than the saline area which resulted higher net return from T. Aman rice farming.
\end{abstract}

Keywords- Saline \& non-saline areas, T. Aman rice, profitability and technical efficiency

\section{Introduction}

The arable land in Bangladesh is about 61 percent of the total land area. The total cultivated area was 8.03 million hectares in 2003 but it reduced to 7.73 million hectares in 2008 (BBS 2012) due to urbanization, industrialization and housing for increasing population. The decreasing trend of arable land requires intensive use of land to produce more food for the extra million future generations. Moreover, out of total cultivated areas, 2.75 million ha is single cropped, 3.92 million ha double cropped and 1.28 million ha triple cropped (BBS 2010). The economic development of Bangladesh is inextricably linked with the performance of Agricultural sector. Agriculture provides nearly about $48.1 \%$ of her labour forces (BBS 2011). This sector contributes about $20.24 \%$ (BBS 2011) to the GDP of the economy as a whole of which crop sector share is about $12 \%$. Rice is the dominating crop sector of agriculture and the largest contributor to farm income of the majority of farm population. However, it is a vital source of non farm income related to trade and commerce of a large segment of the economy. Rice is the most strategic commodity in Bangladesh accounting for $70 \%$ calorie intake and about $35 \%$ of household expenditure. Out of 7.97 million ha cultivated area, about its $77 \%$ devoted to rice (Salam 2012). Rice is being grown in the three seasons namely, Aus, Aman and Boro covering 1.11, 5.65 and 4.77 million ha of land, respectively (BBS 2011).

However, the country contains a large area considered as coastal area. The coastal area of Bangladesh represents an area of $47,211 \mathrm{~km}^{2}, 32$ percent of the country's geographical area, wherein 35 million people i.e. 28 percent of the country's total population live at 6.85 million households. In terms of administrative consideration, 19 districts out of 64 are considered as coastal district (http://equitybd.org/newsletter/english/Issue-5/Disaster BD.pdf). Moreover, the coastal area is suffering from salinity problem for rice cultivation. The large farmers cultivated rice-cum-bagda pattern with the saline water. The productivity of rice is very much lower compare to the other areas of the country. Salinity is a problem for livestock's and forestry also. The marginal farmers' preferred cultivate rice to shrimp as there was alternative of fresh water golda with rice. But, they could not as the large farmers were devoted to shrimp culture with saline water. Realizing the negative impact of saline water on environment and society, people as well as the government recently restricted the intrusion of saline water into the empoldered areas. As rice takes the monopoly position in the staple food items of the country and salinity has great impact on rice production and environment, the people of the polder 31 of Khulna district banned the intrusion of saline water and brought more land under the cultivation of $T$. Aman rice through rice-cum-golda pattern instead of rice-cum-bagda. Due to the restriction of saline water intrusion the soil salinity decreased from previous level (from $29.57 \mathrm{ds} / \mathrm{m}$ to $22.06 \mathrm{ds} / \mathrm{m}$ ). But the land is not free from the salinity effect. The salinity of the concerned area was higher than 
the normal salinity (less than $4 \mathrm{ds} / \mathrm{m}$ ) for rice production (SRDI 2009). This study was designed to compare the technical efficiency of rice farming between the polder 31 as saline area and other selected non-saline areas of Bangladesh. Therefore, the present study was undertaken at farm level with the following specific objectives:

i) to assess profitability of T. Aman rice cultivation in saline and non-saline areas; and

ii) to compare the technical efficiency of $T$. Aman rice growers of the study areas.

\section{Methodology}

Polder 31 in Dacope Upazila of Khulna district was the selected as a saline area, suitable for rice production. A stratified random sampling was used to select 60 rice-cum-golda farmers from Polder 31 . Other 60 sampled farmers were selected from different non-saline districts (such as: Gazipur, Mymensingh, Rangpur, Barishal etc.) of the country with the help of Agricultural Economics Division of Bangladesh Rice Research Institute to fulfill the objectives of the study. Primary data were collected using a structured interview schedule. The secondary data used in this study were from text books, journals, government papers, research reports, online materials and periodicals. Both descriptive statistics and activity budgeting were employed in analyzing the data and identifying the profitability of rice production. The stochastic frontier model using Cobb-Douglas production function was used in measuring farm specific technical efficiency.

To determine per hectare profitability for each of the selected rice farm from the view point of individual farmers, the following algebraic equation was followed:

$\pi=T R-T C$ or,

$\pi=\sum Q_{y} \cdot P_{y}+\sum Q_{b} \cdot P_{b}-\sum_{i=1}^{n}\left(X_{i} \cdot P_{x i}\right)-T F C$

Where, $\pi=$ Net returns from rice (Tk/ha), $Q_{y}=$ Total quantity of (rice) outputs $(\mathrm{kg} / \mathrm{ha}), P_{y}=$ Per unit price of the rice $(\mathrm{Tk} / \mathrm{kg}), Q_{b}=$ Total quantity of the concerned byproduct $(\mathrm{kg} / \mathrm{ha}), P_{b}=$ Per unit price of the relevant byproduct $(\mathrm{Tk} / \mathrm{kg}), X_{i}=$ Quantity of the concerned $\mathrm{i}^{\text {th }}$ inputs, $P_{x i}=$ Per unit price of the relevant $\mathrm{i}^{\text {th }}$ inputs, $T F C=$ Total fixed cost involved in production and $i=1,2,3, \ldots, n$ (number of inputs).

Technical efficiency of T. Aman rice production was estimated with the parameters technique of production functions used by Bravo-Ureta and Evension, 1994 and Xiaosong Xu and Scott R. Jeffrey, 1998 and cost decomposition procedure used by Kopp and Diewert, 1982 to estimate the technical efficiency.

The production function was specified as:

$$
Y_{i}=X_{i} \beta_{i}+\varepsilon_{i}
$$

Where, $Y_{i}=$ yield of rice, $X_{i}=\left(K_{i} \times 1\right)$ matrix of inputs, $\beta_{i}=\left(K_{i} \times 1\right)$ matrix of parameters associated with $X_{i}, \varepsilon_{i}=$ error terms and $i=$ the $i^{\text {th }}$ observation.

The error term $\varepsilon_{i}$ is made up of two independent components,

$$
\varepsilon_{i}=v_{i}-u_{i}
$$

The error component $v_{i}$ represents the symmetrical disturbance that captures random errors/erroneous data. The error component $u_{i}$ is the asymmetrical term that captures the technical inefficiency of the observations and is assumed to be distributed independently of $v_{i}$. Hence, the production frontier may be as follows:

$$
\begin{aligned}
& Y_{i}=X_{i} \beta_{i}+\left(v_{i}-u_{i}\right) \\
& Y_{i}=f\left(X_{i} \beta_{i}\right) \exp \left(v_{i}-u_{i}\right) .
\end{aligned}
$$

Where, $v_{i} \sim \mathrm{N}\left(0, \sigma^{2}{ }_{v}\right)$ and $u$ is the truncated normal. The term $u$ is the one-sided error.

\section{Production frontier estimation with inefficiency equation}

The $u_{i} \mathrm{~s}$ are non-negative random variables, associated with the technical inefficiency of production of the farmers in the production, assumed to be independently distributed such that the technical inefficiency effect for the $i^{\text {th }}$ farmer, $u_{i}$, is obtained by truncation (at zero) of the normal distribution with mean, $\mu_{1}$ and variance, $\sigma^{2}$, such that

$$
u_{i}=\delta_{0}+\delta_{1} z_{1 i}+\ldots+\delta_{n} z_{n i}
$$


Where, $z_{1 i} \ldots z_{n i}$ are explanatory variables.

The maximum likelihood estimates and inefficiency model, defined by equations (4) and (5) are simultaneously obtained by using the computer program FRONTIER Version 4.1 (Coelli, 1996) which estimates the variance parameters in terms of parameterization

$$
\sigma_{\varepsilon}^{2}=\sigma_{v}^{2}+\sigma_{u}^{2}
$$

and

$$
\gamma=\sigma_{u}^{2} / \sigma_{\varepsilon}^{2}
$$

$\gamma$ is the ratio of variance of farm specific technical efficiency to the total variance of output and has a value between zero and one.

The technical efficiency of a farmer at a given period of time is defined as the ratio of the observed output of the frontier output which could be produced by a full-efficient farm, in which the inefficiency effect is zero. Given the specifications of the stochastic frontier models (4 and 5), the technical efficiency of $i^{\text {th }}$ farmer, can be shown to be equal to

$$
\begin{aligned}
T E & =\exp \left(-u_{i}\right) \\
& =Y_{i} / f\left(X_{i} \beta_{i}\right) \exp \left(v_{i}\right)=Y_{i} / Y_{i}^{*}
\end{aligned}
$$

Where, $Y_{i}^{*}=f\left(X_{i} \beta_{i}\right) \exp \left(v_{i}\right)$ is the farm specific stochastic frontier. If $Y_{i}$ is equal to $Y_{i}^{*}$, then $T E_{i}=1$, reflects $100 \%$ efficiency. The difference between $Y_{i}$ and $Y_{i}^{*}$ is embedded in $u_{i}$ (Dey et al., 2000). If $u_{i}=0$, implying that production lies on the stochastic frontier, the farm obtains its maximum attainable output given its level of inputs. If $u_{i}<0$, implies that production lies below the frontier which is an indication of inefficiency.

Thus, the technical efficiency of a farmer is between zero and one, inversely related to the inefficiency effect. It is important to note that the above model for the inefficiency effects (5) can only be estimated if the inefficiency effects are stochastic and have a particular distributional specification. Hence, there is interest to test the null hypotheses that the inefficiency effects are not present;

$$
\mathrm{H}_{0}: \gamma=\delta_{0}=\ldots \ldots=\delta_{4}=0 \text {; and }
$$

The coefficients of the variables in the model for the inefficiency effects are zero,

$$
\mathrm{H}_{0}: \delta_{0}=\ldots \ldots=\delta_{4}=0 \text {. }
$$

These null hypotheses are tested using the generalized likelihood-ratio statistic, $\lambda$, defined by

$$
\lambda=-2\left[\ln \left\{\mathrm{L}\left(\mathrm{H}_{0}\right)\right\}-\ln \left\{\mathrm{L}\left(\mathrm{H}_{1}\right)\right\}\right]
$$

Where, $\mathrm{L}\left(\mathrm{H}_{0}\right)$ and $\mathrm{L}\left(\mathrm{H}_{1}\right)$ are the values of the likelihood function under the specifications of the null and alternative hypotheses $\left(\mathrm{H}_{0}\right.$ and $\mathrm{H}_{1}$, respectively. If the null hypothesis is true then, $\lambda$ has approximately a Chisquare (or a mixed Chi-square) distribution (see Coelli, 1995).

\section{Empirical Model}

Cobb-Douglas and translog are two functions that dominate the technical efficiency in the literature. Since, the sample number is not very high, the translog specification could not be employed. The stochastic production function for the sample farmers is specified as:

$$
\ln Y_{i}=\beta_{0}+\beta_{1} \ln \left(X_{1}\right)+\beta_{2} \ln \left(X_{2}\right)+\beta_{3} \ln \left(X_{3}\right)+\beta_{4} \ln \left(X_{4}\right)+\beta_{5} \ln \left(X_{5}\right)+\beta_{6} \ln \left(X_{6}\right)+\varepsilon_{i}
$$

Where, $\ln =$ Natural logarithm; $Y_{i}=$ Yield of rice (kg/ha); $X_{1}=$ Seed (kg/ha); $X_{2}=$ Labour (man-days $\left./ \mathrm{ha}\right)$; $X_{3}=$ Urea (kg/ha); $X_{4}=\operatorname{TSP}$ (kg/ha); $X_{5}=\operatorname{MoP}(\mathrm{kg} / \mathrm{ha}) ; X_{6}=$ Insecticides/pesticides (No./ha); $\beta_{0}=$ Constant and $\beta_{i}=$ Coefficients.

$\varepsilon_{i}=$ Statistical noise/random disturbance term (in estimating technical inefficiency effects). This $\varepsilon_{i}$ is further decomposed as $v_{i}-u_{i}$ where $v_{i}=$ random error and $u_{i}=$ non-negative random term associated with technical inefficiency. 
The technical inefficiency effects, $u_{i}$ is defined as:

$u_{i}=\delta_{0}+\delta_{j} Z_{i}$

Where, $\delta_{j}=$ Unknown parameter to be estimated; $Z_{1}=$ Age of $i^{\text {th }}$ farmer (year); $Z_{2}=$ Education (years of schooling); $Z_{3}=$ Training (dummy: 1 , if trained, 0 otherwise) and $Z_{4}=$ Farm size (ha).

Frontier 4.1 packages (Coelli, 1996) was used to estimate the stochastic production function, which measures the inefficiency of the sample farms.

Finally, the independent-sample T-test was done to compare the level of technical efficiencies of farmers' of two different regions under the null hypothesis:

$\mathrm{H}_{0}$ : Salinity has no impact on farming efficiency of $T$. Aman rice farmer.

\subsection{Comparative Input Use Pattern and Productivity}

\section{Result And Discussion}

The comparative input use pattern and productivity of $T$. Aman rice cultivation in between non-saline and saline areas are presented in Table 1 . The rice farmers at the both study areas used substantially more seed than the recommended rate $(30 \mathrm{~kg} / \mathrm{ha})$. Moreover, the use of seed in saline area was higher $(88 \mathrm{~kg} / \mathrm{ha})$ than that of non-saline areas $(57 \mathrm{~kg} / \mathrm{ha})$. Most of the saline areas rice growers used home supplied seed, whose germination rate was lower than quality seed. So, the farmers inclined to use more amounts of seeds than the recommendation.

The analysis reveals that there was significant mean difference at fertilizer application between the non-saline and saline areas. The T. Aman rice growers at non-saline areas, fertilizer applied on an average 170, 52 and $37 \mathrm{~kg} / \mathrm{ha}$ of Urea, TSP and MP respectively, while the saline areas rice growers used at the rate of 100, 69 and $20 \mathrm{~kg} / \mathrm{ha}$ indicating that non-saline areas rice growers used more amount of chemical fertilizers than that of saline areas. It is also important to mention that the majority of non-saline areas rice farmers used Gypsum (21 $\mathrm{kg} / \mathrm{ha}$ ), but none of the farmers of saline areas used this fertilizer.

The saline areas farmers used on an average 41 man-days/ha, while non-saline areas rice growers used 89 man-days/ha. It indicated that human labour requirement in the non-saline areas was higher than that of saline area for T. Aman rice production.

The average yield of main product (rice) was $3845 \mathrm{~kg} / \mathrm{ha}$ for the non-saline farms and that of 3433 $\mathrm{kg} / \mathrm{ha}$ for the saline area. The average return from by product (straw) was $7286 \mathrm{Tk} / \mathrm{ha}$ and $6131 \mathrm{Tk} / \mathrm{ha}$ for the non-saline and saline water farms, respectively. So, the yield of rice in non-saline areas is $12 \%$ higher than that of saline area, while the by-product of non-saline farms is $19 \%$ higher than that of saline farms.

\subsection{Comparative Cost and Return of T. Aman Rice Production}

Per hectare costs and returns of T. Aman rice production is presented in Table 2. Average human labour cost for T. Aman rice cultivation in saline and non-saline areas were estimated to be Tk. 11,250 and Tk. 15,250 per hectare, respectively which was the highest share (33.98\% \& 42.09\%, respectively) of total cost. Costs of seedlings was higher in saline areas (Tk. 3,744/ha) than that of non-saline (Tk. 3,212/ha). Cost of fertilizer was higher in non-saline areas (Tk. 4,887/ha) whereas manure and insecticides costs (Tk. 631/ha and Tk. 1,346/ha, respectively) were higher in saline area. It was evident that there was no cost for irrigation as the farmers used flood, rain and drain water through sluice gate management and voluntary action of the gate committee. Average family labour cost and interest on operating capital were Tk. 7,000/ha and Tk. 428/ha for saline area and that of non-saline areas were Tk. 6,500/ha and Tk. 487/ha, respectively. Per hectare total cost for T. Aman rice production in the saline and non-saline areas were Tk. 33,109 and Tk. 36,231 where as total returns were Tk. 58,237 and Tk. 65,811, respectively. The gross margin and net return were estimated as Tk. 32,556/ha and Tk. $25,128 /$ ha, respectively for saline farms and that of Tk. 36,567/ha and Tk. 29,580/ha for non-saline farms. The farmers got Tk. 1.75 by investing Tk. 1.00 in T. Aman rice cultivation in the saline area and that of Tk. 1.82 in the non-saline areas as the benefit cost ratios (BCR) were 1.75 and 1.82 , respectively.

\subsection{Estimates of Stochastic Frontier Production Function for T. Aman Rice Production}

The comparative maximum likelihood estimates of the parameters of the Cobb-Douglas stochastic production frontier of saline and non-saline areas for T. Aman rice are presented in Table 3. The empirical analysis revealed that the coefficients of the variables in the frontier function are the elasticity of average output with respect to the different inputs used in the rice production as specified in the earlier equation (equation no. 10). The empirical result showed that, the sign and magnitudes of the estimated $\beta$ coefficient in majority cases were consistent with prior expectation although some of them were statistically insignificant. 
The estimated coefficient of seed was negative and significant, both of saline and non-saline areas at $5 \%$ and $1 \%$ level, respectively. This implies that the amount of seed should reduce to get better production of rice. The coefficients of labour was positive and significant at $10 \%$ level in saline area only, which implies that if the application of labour increased by $1 \%$, the yield of rice would be increased by $0.113 \%$ in the saline area. The coefficient of Urea and TSP were anticipated at 5\% and 10\% level of significant only in non-saline areas, implying that if the amount of Urea and TSP increased by $1 \%$, the yield of rice would be increased by $0.008 \%$ and $0.021 \%$, respectively in the non-saline areas. The coefficient of MoP and insecticides were positive and significant at both of saline and non-saline areas which means, the farmers should increase the application of $\mathrm{MoP}$ and insecticides to get better production from T. Aman rice.

Among the inefficiency factors, the coefficients of age of the farmers was positive in saline area and significant at $10 \%$ level that imply, the age of farmers in saline areas farm had inverse relationship with farming efficiency. But it has negative and significant coefficient in case of non-saline areas. That means, if the age of farmers increase, the inefficiency of farming in saline areas rice will be increased and decreased in case of nonsaline areas. The coefficient of education and training were negative and significant at $10 \%$ and $5 \%$ level, respectively for both of saline and non-saline farms. So, it can be evident that if the farmers had higher education, their inefficiency would decrease meaning that their efficiency would be increased and the trained farmers were technically sounder than others. In other words, the level of the inefficiency effect of farmers tends to decrease with increase in training on farming of $T$. Aman rice farmers.

\subsection{Hypothesis Testing}

Table 4 presents the results of null hypothesis of interest. The result of the first hypothesizes were strongly rejected as the computed LR were greater than the tabulated $\chi^{2}$, indicating that there was presence of technical inefficiency effects in the production in case of both saline and non-saline farms. Confirming this result further is the result of the gamma $(\gamma)$ ( 0.988 and 0.924 for the saline and non-saline farms, respectively) of the preferred model in the lower part of Table 3. $\gamma$ is very close to one and significantly different from zero, thereby establishing the fact that high level of inefficiencies exist among the sample farmers. The second hypothesis was also rejected in both cases (saline and non-saline areas). This means that the determinants of the technical inefficiency significantly contribute to the differences in the farmers' technical efficiencies.

\subsection{Level of Technical Efficiency of T. Aman Rice Farmers}

It is evident from Table 5 that the mean value of technical efficiency was about $70.70 \%$ with a range from about $11 \%$ to $93 \%$ for the saline areas farms. About $31.67 \%$ (19 sample farmers) farms attained efficiency belongs to $81 \%-90 \%$ category. In case of Non-saline areas farms the mean technical efficiency was about $87.50 \%$ with a range from about $54 \%$ to $96 \%$. Near $51.67 \%$ (31 sample farmers) farms were belongs to efficiency level category $81 \%-90 \%$. The estimated result also showed that there is a greater scope of increasing yield, breaking the frontier for $T$. Aman rice production in the study areas. The yield of $T$. Aman rice could be increased about $29 \%$ and $22 \%$ incase of saline and non-saline areas, respectively even with the existing technologies if the management practices of the identified parameters are improved.

\subsection{T-test}

The independent samples T-test has been done to test the null hypothesis of impact of salinity on farming efficiency of T. Aman rice farmers. Taking the level of technical efficiencies of 60 saline and non-saline farmers, the calculated value at 99 percent confidence interval was 6.967. So, there was no enough evidence to accept the null hypothesis. That means, the technical efficiency of T. Aman rice farming significantly differs between the two conditions (saline and non-saline). So, Salinity had significant impact on farming efficiency of T. Aman rice farmers.

\section{Tables}

Table 1: Use of Inputs for T. Aman Rice Production in Saline and Non-saline Areas

\begin{tabular}{|l|l|l|l|}
\hline Items & Non-saline & Saline & $\begin{array}{c}\text { Mean difference } \\
\text { t-ratio }\end{array}$ \\
\hline Seed (kg/ha) & 57 & 88 & $-31^{* * *}$ \\
\hline Urea (kg/ha) & 170 & 100 & $70^{* * *}$ \\
\hline TSP (kg/ha) & 52 & 69 & $-17^{* *}$ \\
\hline MoP (kg/ha) & 37 & 20 & $17^{* * *}$ \\
\hline Gypsum (kg/ha) & 21 & 0 & $21^{* * *}$ \\
\hline Insecticides (No.) & 1.35 & 1.24 & $0.11^{\mathrm{ns}}$ \\
\hline Plough (No.) & 2.67 & 1.62 & $1.05^{* * *}$ \\
\hline $\begin{array}{l}\text { Human labour } \\
\text { (man-days/ha) }\end{array}$ & 89 & 41 & $48^{* * *}$ \\
\hline
\end{tabular}


Farm Level Evaluation Of T. Aman Rice Cultivation In Selected Saline And Non-Saline Areas Of

\begin{tabular}{|l|l|l|l|}
\hline Yield performance: & & & \\
\hline - Product (kg/ha) & 3845 & 3433 & $371^{*}$ \\
\hline - By product (Tk/ha) & 7286 & 6131 & $1155^{*}$ \\
\hline
\end{tabular}

$* * *, * *, *$ and $^{\mathrm{ns}}=$ Significant at $1 \%, 5 \%, 10 \%$ level and not significant, respectively.

Table 2: Per Hectare Costs and Returns of T. Aman Rice Production

\begin{tabular}{|c|c|c|}
\hline \multirow{2}{*}{ Items of cost } & Saline & Non-saline \\
\hline & Cost (Tk/ha) & Cost $(\mathrm{Tk} / \mathrm{ha})$ \\
\hline Hired labour & $\begin{array}{l}11,250 \\
(33.98)\end{array}$ & $\begin{array}{l}15,250 \\
(42.09)\end{array}$ \\
\hline Power tiller & $\begin{array}{c}4,940 \\
(14.92)\end{array}$ & $\begin{array}{c}4,940 \\
(13.63)\end{array}$ \\
\hline Seedlings & $\begin{array}{c}3,744 \\
(11.31)\end{array}$ & $\begin{array}{l}3,212 \\
(8.87)\end{array}$ \\
\hline Fertilizers cost & $\begin{array}{c}3,770 \\
(11.38)\end{array}$ & $\begin{array}{c}4,887 \\
(13.49)\end{array}$ \\
\hline Manure & $\begin{array}{c}631 \\
(1.91)\end{array}$ & $\begin{array}{c}130 \\
(0.36)\end{array}$ \\
\hline Insecticides/pesticides & $\begin{array}{l}1,346 \\
(4.07) \\
\end{array}$ & $\begin{array}{c}825 \\
(2.28) \\
\end{array}$ \\
\hline Total variable cost & $\begin{array}{l}25,681 \\
(77.57)\end{array}$ & $\begin{array}{l}29,244 \\
(80.72)\end{array}$ \\
\hline Family labour & $\begin{array}{c}7,000 \\
(21.14)\end{array}$ & $\begin{array}{c}6,500 \\
(17.94)\end{array}$ \\
\hline IOC@ $10 \%$ for 4 month $^{*}$ & $\begin{array}{c}428 \\
(1.29)\end{array}$ & $\begin{array}{c}487 \\
(1.34)\end{array}$ \\
\hline Total cost & 33,109 & 36,231 \\
\hline Gross return & 58,237 & 65,811 \\
\hline Gross margin & 32,556 & 36,567 \\
\hline Net return & 25,128 & 29,580 \\
\hline Undiscounted BCR & 1.75 & 1.82 \\
\hline
\end{tabular}

Source: Field Survey (2012). Figures in the parenthesis represent the standard error.

*IOC $=$ Interest on Operating Capita

Table 3: Maximum Likelihood Estimation of Stochastic Cobb-Douglas Production Frontier for T. Aman Rice Production in Saline and Non-saline Areas

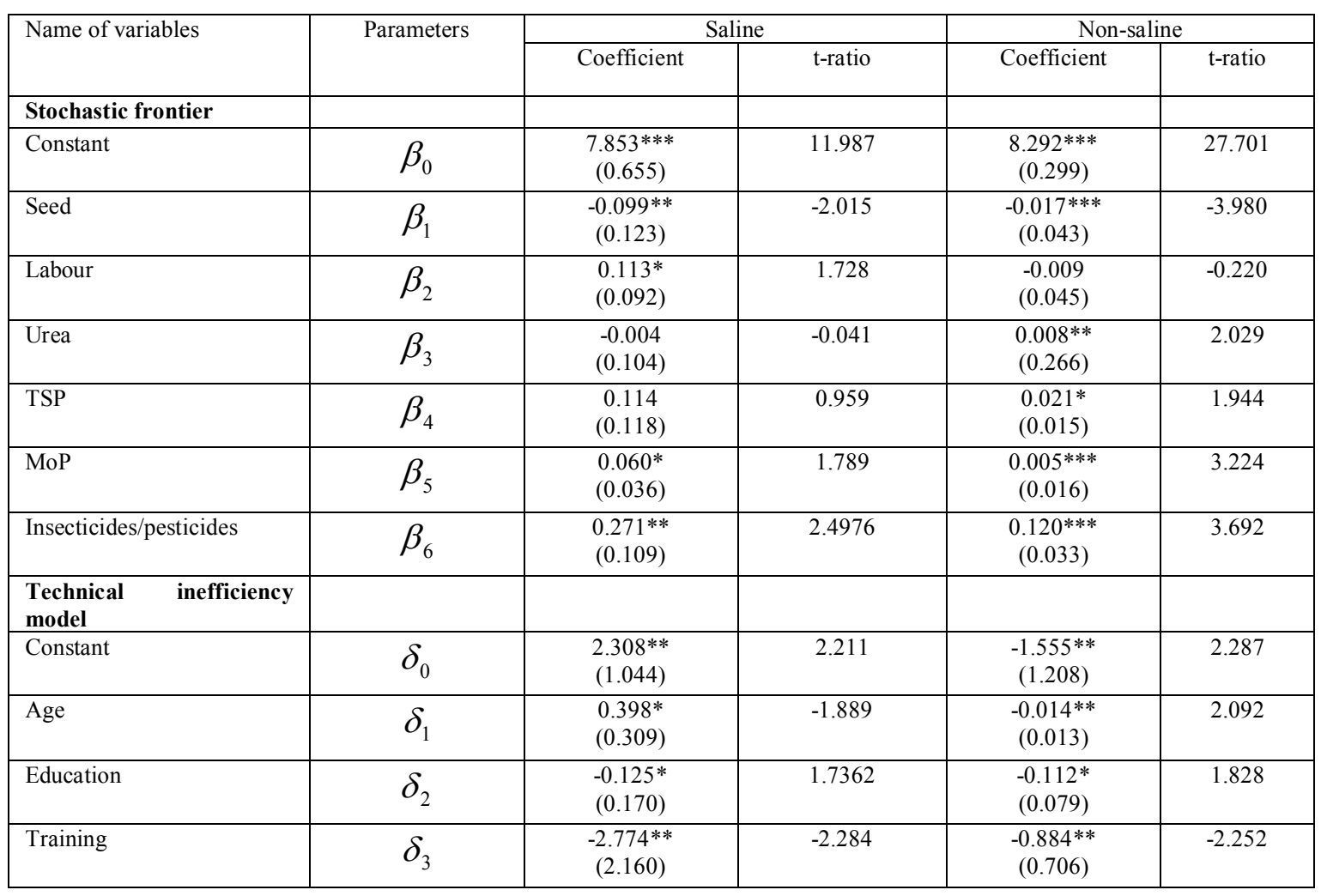


Farm Level Evaluation Of T. Aman Rice Cultivation In Selected Saline And Non-Saline Areas Of

\begin{tabular}{|l|c|c|c|c|c|}
\hline Farm size & $\delta_{4}$ & $\begin{array}{c}0.019 \\
(0.013)\end{array}$ & 1.423 & $\begin{array}{c}-0.002 \\
(0.004)\end{array}$ & 0.547 \\
\hline Log likelihood value & & -55.19 & & 12.67 & \\
\hline Mean technical efficiency & & 0.694 & & 0.875 & \\
\hline Variance parameter & & & & & $0.110^{* *}$ \\
\hline Sigma-square & $\sigma^{2}$ & $\begin{array}{c}5.415^{* * *} \\
(1.289)\end{array}$ & 4.200 & $0.039)$ & 2.795 \\
\hline Gamma & $\gamma$ & $\begin{array}{c}0.988^{* * *} \\
(0.010)\end{array}$ & 96.682 & $0.924^{* * *}$ & 7.121 \\
& & & $(0.112)$ & \\
\hline
\end{tabular}

***, ** and $*$ indicate significant at $1 \%, 5 \%$ and $10 \%$ level, respectively.

Figures in the parenthesis represent the standard error.

Table 4: Generalized Likelihood Ratio Test of Null Hypotheses for Parameters of the Inefficiency Function

\begin{tabular}{|c|c|c|c|c|c|c|c|c|}
\hline \multirow[b]{2}{*}{$\begin{array}{l}\text { Test of null } \\
\text { hypothesis }\end{array}$} & \multicolumn{4}{|c|}{ Saline } & \multicolumn{4}{|c|}{ Non-saline } \\
\hline & $\begin{array}{c}\text { Test } \\
\text { statistics } \\
(\lambda)^{\mathrm{a}}\end{array}$ & $\begin{array}{l}\text { Degrees } \\
\quad \text { of } \\
\text { freedom }\end{array}$ & $\begin{array}{c}\text { Critical } \\
\text { values at } \\
95 \% \\
\left(\chi^{2} 0.05\right)\end{array}$ & $\begin{array}{c}\text { Conclusio } \\
\mathrm{n}\end{array}$ & $\begin{array}{c}\text { Test } \\
\text { statistics } \\
(\lambda)^{\mathrm{a}}\end{array}$ & $\begin{array}{l}\text { Degrees of } \\
\text { freedom }\end{array}$ & $\begin{array}{c}\text { Critical } \\
\text { values at } \\
95 \% \\
\left(\chi^{2} 0.05\right)\end{array}$ & Conclusion \\
\hline $\begin{array}{l}\text { Farmers are } \\
\text { completely efficient } \\
\text { in producing rice } \\
\left(\gamma=\delta_{0}=\delta_{1}=\delta_{2}=\delta_{3}=\right. \\
\left.\boldsymbol{\delta}_{4}=\boldsymbol{0}\right)\end{array}$ & 29.14 & 6 & 12.59 & $\begin{array}{c}\text { Reject } \\
\mathrm{H}_{0}\end{array}$ & 30.22 & 6 & 12.59 & Reject $\mathrm{H}_{0}$ \\
\hline $\begin{array}{l}\text { No effect of age, } \\
\text { education, training } \\
\text { and farm size } \\
\left(\boldsymbol{\delta}_{1}=\boldsymbol{\delta}_{2}=\boldsymbol{\delta}_{3}=\boldsymbol{\delta}_{4}=\boldsymbol{0}\right)\end{array}$ & 18.26 & 4 & 9.49 & $\begin{array}{c}\text { Reject } \\
\mathrm{H}_{0}\end{array}$ & 23.88 & 4 & 9.49 & Reject $\mathrm{H}_{0}$ \\
\hline
\end{tabular}

Source: Frontier 4.1 package program, ${ }^{\mathrm{a}} \lambda=-2\left[\ln \left\{\mathrm{L}\left(\mathrm{H}_{0}\right)\right\}-\ln \left\{\mathrm{L}\left(\mathrm{H}_{1}\right)\right\}\right]$.

Table 5: Level of Technical Efficiency for T. Aman Rice Producers

\begin{tabular}{|l|c|c|}
\hline \multirow{2}{*}{ Technical efficiency (\%) } & \multicolumn{2}{|c|}{ No. of farmers } \\
\cline { 2 - 3 } & Saline & 2 \\
\hline$<60$ & 15 & 2 \\
\hline $71-80$ & 6 & 31 \\
\hline $81-90$ & 17 & 22 \\
\hline $91-100$ & 19 & 60 \\
\hline No. of farms & 3 & 0.54 \\
\hline Minimum efficiency & 60 & 0.96 \\
\hline Maximum efficiency & 0.11 & 0.079 \\
\hline Standard deviation & 0.93 & 0.875 \\
\hline Mean efficiency & 0.168 & 0.707 \\
\hline
\end{tabular}

Source: Author's estimation.

\section{Conclusion}

The objectives of this study were to examine the comparative resource profitability and technical efficiency of rice farmers in selected saline and non-saline areas of Bangladesh. The net returns of T. Aman rice were Tk. 25,128/ha and Tk. 29,580/ha incase of saline and non-saline farms, respectively. The farmers received higher return on investment in rice production in the non-saline areas as BCR was higher (1.82) than the saline area (1.75). The coefficients of urea and TSP had significant impact on the non-saline areas but not in the saline area. The coefficient of seed, labour, MoP and insecticides were significant at both of saline and non-saline areas. The average technical efficiencies for T. Aman rice were about $70.70 \%$ and $87.50 \%$ for the saline and non-saline farms, respectively. This implies that the output per farm can be increased, on an average, $29 \%$ and $12.50 \%$ in saline and non-saline areas, respectively without incurring any additional production cost. The coefficients of farmer's education and training had significant positive effect on efficiency for rice production. If the efficient management of the existing resources can be ensured and modern variety of seed and technology is available to the farmers, yield and production can be increased which may help to increase their income and 
ensure food security. However, the salinity had negative and significant impact on the efficiency of $T$. Aman rice farming. So, the saline tolerant varieties or salinity controlling technologies may be introduced to the saline areas to boost up rice production.

\section{Acknowledgement}

The author is grateful to International Water Management Institute (IWMI) leading subproject 'G3: Water Governance and Community Based Management, Ganges Basin Development Challenges of the CPWF (CGIAR Challenge Program on Water and Food)' for granting fellowship to undertake this research program. The author would like to acknowledge the untiring inspiration, encouragement and valuable guidance provided by the scientists of Agricultural Economics Division, Bangladesh Rice Research Institute, Gazipur.

\section{References}

[1] BBS, 2012. 'Statistical Year Book of Bangladesh', Bangladesh Bureau of Statistics, Ministry of Planning, Government of the People's Republic of Bangladesh, Dhaka.

[2] BBS, 2010. 'Bangladesh Population Census', Bangladesh Bureau of Statistics, Ministry of Planning, Government of the People's Republic of Bangladesh, Dhaka.

[3] BBS, 2011. 'Statistical Year Book of Bangladesh', Bangladesh Bureau of Statistics, Ministry of Planning, Government of the People's Republic of Bangladesh, Dhaka.

[4] Salam M. A., 2012. 'Assessment of Technical Efficiency of Inbred HYV and Hybrid Rice Cultivation at Farm Level'. Bangladesh Journal of Agricultural Research 37(2): 235-50.

[5] SRDI, 2009. Survey Report, 'Soil Resource Development Institute', Brackish Water Station, Shatkhira, Bangladesh.

[6] Bravo-Ureta, B. E. and R. E. Evension, 1994. Efficiency in agricultural production: The case of peasant farmers in Eastern Paraguay. Agricultural Economics 10(2): 27-37.

[7] Xiaosong, Xu and S. R. Jeffrey, 1998. Efficiency and Technical Progress in Traditional and Modern Agriculture: Evidence from Rice Production in China. Agricultural Economics 18(2): 157-65.

[8] Kopp, R. J. and V. K. Smith, 1982. Frontier production function estimates for steam electric generation: A comparative analysis. Southern Economic Journal 47(10): 49-59.

[9] Coelli, T. J., 1996. A Guide to Frontier Version 4.1: A Computer Program for Stochastic Frontier Production and cost function Estimation. CEPA working paper 7/96, Centre for Efficiency and Productivity Analysis, University of New England, Armidale.

[10] Dey, M. M., G. P. Bimbao, F. J. Paraguas and P. B. Regaspi, 2000. 'Technical Efficiency of Tilapia Grow-out Pond Operations in the Philippines'. Agricultural economics and Management 4(1\&2): 33-46.

[11] Coelli, T. J., 1995. Estimators and Hypothesis Tests for a Stochastic Frontier Function: A Monte Carlo Study. Journal of Productivity Analysis 6: 247-68.

[12] Battese, G. E. and T. J. Coelli, 1993. 'A Stochastic Frontier Production Function Incorporating a Model for Technical Inefficiencies Effect', Working Paper in Economics and Applied Statistics, No.69. 